\title{
An analysis of general surgery theses set up between years 1998-2018 in Turkey: Evidence levels and publication rates of 1996 theses
}

\author{
Murat Ferhat Ferhatoğlu' (ID), Taner Kıvılcım('(ID), Abdulcabbar Kartal' (ID), Ali Illker Filiz' (ID), Abut Kebudi (ID) \\ ${ }^{1}$ Department of General Surgery, Okan University School of Medicine, Istanbul, Turkey
}

\begin{abstract}
Objective: Setting up and advocating a thesis is mandatory at the end of the residency training program to become a specialist in general surgery according to the regulations on medical specialization in Turkey. Writing a thesis helps the resident to learn to ask structured questions, assembling the most accurate study design, managing the study process, collecting the results and building a conclusion with medical implications. In this descriptive study, we aimed to investigate the publication rates of the theses written in the field of general surgery and to assess the properties of the published theses.
\end{abstract}

Material and Methods: We performed an online search on September 1,2018, about the theses of general surgery residents on the website of National Thesis data center of Academic Educational Board in Turkey including theses of medical residents in university-affiliated hospitals and analyzed theses accomplished between 1998-2018. The publication status of the theses was assessed by the entry of author name, the title of the theses and keywords of the theses by using the search engines of PubMed, Google Scholar and Turkish Academic Network and Information Center Turkish Database (ULAKBIM). Data were presented in a descriptive form as absolute numbers and percentages.

Results: Between 1998-2018, 1996 theses were completed. 393 (20.5\%) of these were published in a journal, and 288 (14.4\%) were published in a journal indexed in SCl/SCIE. According to research methodologies, $79.2 \%$ of the experimental studies were published in SCI/SCIE indexed journals.

Conclusion: Publication rates of the theses in the field of general surgery are low as they are in other specialties of medicine. This descriptive study might give an idea about the low scientific publication rates of general surgery theses. Further studies are needed to understand the underlying factors, which are responsible for this scant scientific performance.

Keywords: Thesis, publication, residency, general surgery, surgical education

Cite this article as: Ferhatoğlu MF, Kıvılcım T, Kartal A, Filiz Al, Kebudi A. An analysis of general surgery theses set up between years 1998-2018 in Turkey: Evidence levels and publication rates of 1996 theses. Turk J Surg 2020; 36 (1): 9-14.

Corresponding Author Murat Ferhat Ferhatoğlu E-mail: ferhatferhatoglu@gmail.com

Received: 20.12.2018

Accepted: 27.05.2019

Available Online Date: 18.03 .2020

( Copyright 2020 by Turkish Surgical Society Available online at www.turkjsurg.com

DOI: $10.5578 /$ turkjsurg.4405

\section{INTRODUCTION}

The first of many scientific steps for a medical resident is to accomplish a thesis in the field of his/her. Creating a thesis enlightens the medical residents about how to ask structured questions, assembling the most accurate study design, manage the study process, collecting the results and building a conclusion with medical implications $(1,2)$. Moreover, publishing a thesis as an article in scientific journals makes it more valuable (3). Also, the publication of a thesis may give an idea about the scientific quality of the institution (4). Setting up a thesis is mandatory to become a specialist in general surgery according to the regulations on medical specialization in Turkey. However, the publication of the thesis in a scientific journal is not obligatory. Publishing thesis in a scientific journal increases the merit and accessibility of the thesis (5). However, rate of the theses published in a scientific journal is not high in our country $(1,6)$. In this descriptive study, we aimed to investigate the publication rates of the theses written in the field of general surgery and to assess the properties of the published theses.

\section{MATERIAL and METHODS}

In this retrospective observational study, we performed an online search on September 1, 2018, regarding the theses of general surgery residents on the website of National Thesis data center of Academic Educational Board in Turkey, which includes the theses of medical residents in university-affiliated hospitals, and analyzed the theses conducted between 1998-2018. We selected "General surgery" in the "Department" tab and collected information about the publishing years, author 
names, thesis names, nature of the theses. The publication status of the theses was assessed by the entry of author name, the title of the theses and keywords of the theses by using the search engines of PubMed, Google Scholar and Turkish Academic Network and Information Center Turkish Database (ULAKBIM).

We divided subjects of the published theses into 14 main topics; endocrine diseases, upper gastrointestinal system diseases (not including bariatric surgery or obesity), bariatric surgery/obesity, intestines and colorectal diseases, breast diseases, hepatopancreaticobiliary diseases, endoscopy, hernia diseases, transplantation, peritoneum/ omentum diseases, surgical diseases of skin, trauma, sepsis-shock and miscellaneous (nursing, patient behaviors, basic science, other topics). Research methodologies of the published thesis were assessed under two groups; clinical and experimental. We analyzed the distribution of the published theses according to journal scope as SCI/SCIE indexed journals, ULAKBIM indexed journals, national and international journals (not indexed in SCI/SCIE, and ULAKBIM). We also determined published theses according to Levels of Evidence and Grades of Recommendation System (Table 1) (7).

Number Cruncher Statistical System (NCSS) 2007 (Kaysville, Utah, USA) program was used for statistical analysis. Descriptive statistical methods (mean, standard deviation, median, first quadrant, third quadrant, frequency, percentage, minimum, maximum) were used evaluating the study data. Pearson chi-square test, Fisher's exact test and Fisher-Freeman-Halton exact test were used to compare qualitative data. Statistical significance was accepted as $p<0.05$.

\section{RESULTS}

Between 1998-2018, 1996 theses were completed. 393 (20.5\%) of those theses were published in a journal. And, 288 (14.4\%) of those theses were published in a journal indexed in SCI/SCIE. Research methodologies and journal information are shown in Table 2. Publication years of the theses are shown in Figures 1, 2. According to research methodologies, $79.2 \%$ of the experimental studies were published in SCI/SCIE indexed journals (Table 3).

According to the subject of the published theses, the percentage of publication in SCI/SCIE indexed journals was statistically significant $(p<0.001)$. As a result of post-hoc analysis, SCI/SCIE indexed journal publication percentages of the theses on peritoneum/omentum diseases and skin diseases/wound healing were higher ( $p=0.003$ and $p=0.022$; respectively). In addition, $\mathrm{SCl} / \mathrm{SCIE}$ indexed journal publication percentages of the theses about upper gastrointestinal system diseases and breast diseases were found to be lower ( $p=0.014, p<0.001$ ) (Table 4). Sub analysis of the thesis subjects according to research methodology, number of experimental studies in intestines/Colon/Rectum/Anus, hepatopancreaticobiliary system, miscellenous, peritoneum/omentum, endocrine diseases group were 31 (41.3\%), 25 (37.3\%), 20 (60.6\%), 30 (100\%), 13 (46.4\%), 12 (100\%), respectively.

According to Levels of Evidence and Grades of Recommendation System evaluation, $76.8 \%$ of the published theses were in Level II (Figure 3).

\section{Table 1. Levels of Evidence and Grades of Recommendation System}

\begin{tabular}{|l|l|}
\hline Level I & Studies consisted of high-quality randomized controlled trials \\
\hline Level II & Studies consisted of lesser-quality randomized controlled trials and prospective comparative studies \\
\hline Level III & Studies were made up of case-control and retrospective comparative studies \\
\hline Level IV & Case series with no controls \\
\hline
\end{tabular}

Table 2. Research methodologies and indexation info of the published thesis

\begin{tabular}{|l|c|c|}
\hline & & $\mathbf{n}(\%)$ \\
\hline Research methodologies & $\begin{array}{c}\text { Experimental study } \\
\text { Clinical study }\end{array}$ & $194(49.3)$ \\
\hline SCI/SCIE indexed journal & Yes & $280.6)$ \\
\hline ULAKBIM indexed journal & Yes & $23.2)$ \\
\hline Other journals & Yes & $82.9)$ \\
\hline International journal & Yes & $339(86.8)$ \\
\hline National journal & Yes & $54(13.7)$ \\
\hline Publishing time (years) & Mean \pm SD & $3.83 \pm 2.98$ \\
\end{tabular}




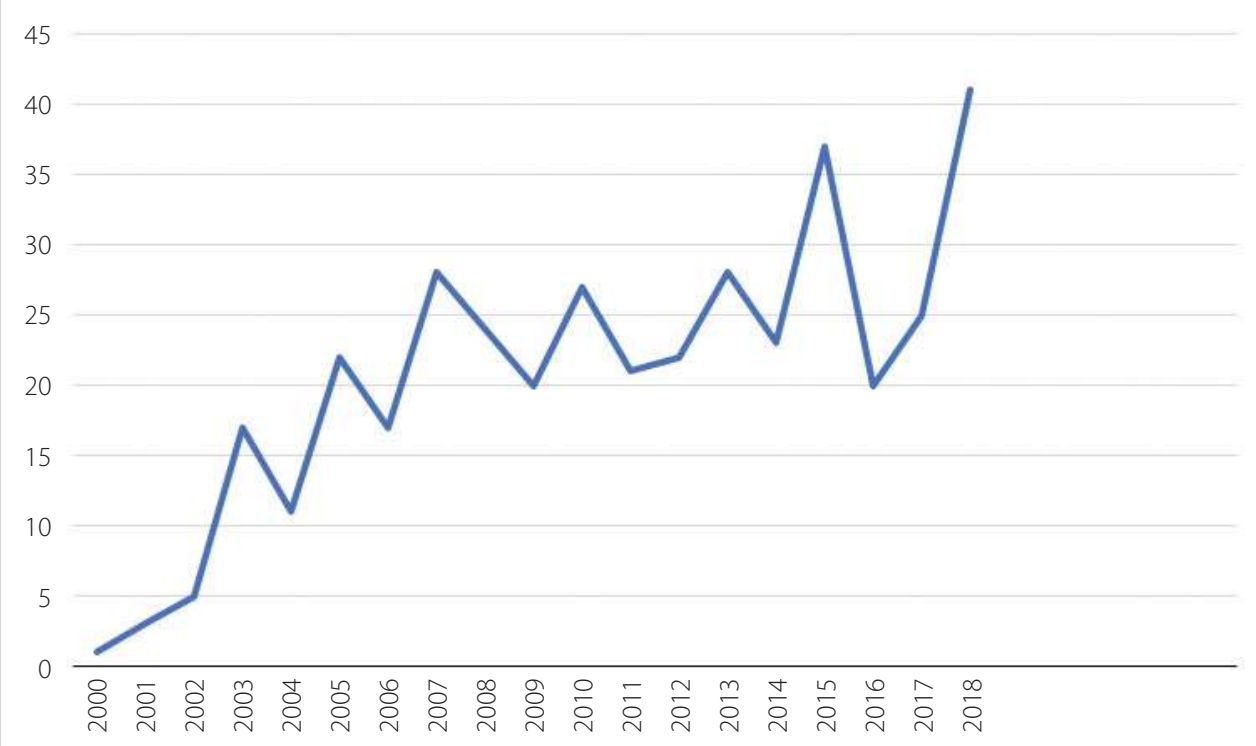

Figure 1. Publication numbers of the theses.

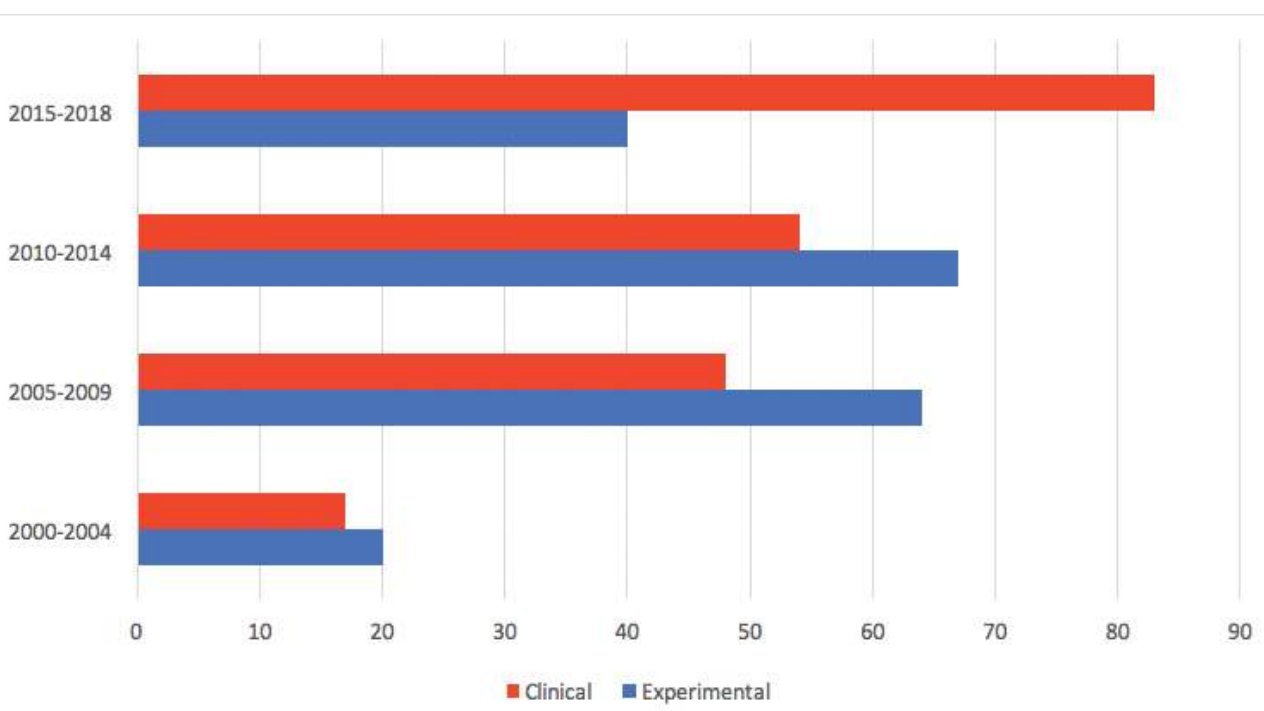

Figure 2. Research methodologies according to 5 year-periods.

Table 3. Publication rates of theses according to research methodologies in international and SCI/SCIE indexed journals

\begin{tabular}{|c|c|c|c|c|}
\hline & & \multicolumn{2}{|c|}{ Research methodologies } & \multirow[b]{2}{*}{$\mathrm{p}$} \\
\hline & & Experimental & Clinical & \\
\hline \multirow[t]{2}{*}{ SCI/SCIE indexed } & No & $45(20.8 \%)$ & $71(33 \%)$ & \multirow[t]{2}{*}{0.007} \\
\hline & Yes & $149(79.2 \%)$ & $144(67 \%)$ & \\
\hline \multirow[t]{2}{*}{ International } & No & $29(11.8 \%)$ & $33(15.3 \%)$ & \multirow[t]{2}{*}{0.309} \\
\hline & Yes & 165 (88.2\%) & $182(84.7 \%)$ & \\
\hline
\end{tabular}




\begin{tabular}{|c|c|c|c|c|}
\hline & Total & $\mathrm{SCI} / \mathrm{SCIE}$ & $\mathrm{p}$ & p (row vs. rest) \\
\hline Intestines/Colon/Rectum/Anus & 100 & $75(75 \%)$ & $<0.001^{\mathrm{a}}$ & $0.248^{c}$ \\
\hline Hepatopancreaticobiliary system & 84 & $67(83.1 \%)$ & & $0.389^{c}$ \\
\hline Miscellaneous & 41 & $33(80.4 \%)$ & & $0.136^{c}$ \\
\hline Peritoneum/omentum & 32 & $30(93.7 \%)$ & & $0.003^{c}$ \\
\hline Endocrine diseases & 28 & $16(57.1 \%)$ & & $0.111^{\mathrm{C}}$ \\
\hline Skin diseases/wound healing & 12 & $12(100 \%)$ & & $0.022^{b}$ \\
\hline Diseases of upper gastrointestinal system & 18 & $8(44.4 \%)$ & & $0.014^{c}$ \\
\hline Breast disease & 27 & $10(37 \%)$ & & $<0.001^{c}$ \\
\hline Hernia disease & 13 & $8(61.5 \%)$ & & $0.539^{b}$ \\
\hline Bariatric surgery/obesity & 8 & $7(87.5 \%)$ & & $0.446^{b}$ \\
\hline Transplantation & 14 & $9(64.2 \%)$ & & $0.566^{b}$ \\
\hline Endoscopy & 4 & $4(100 \%)$ & & $0.324^{b}$ \\
\hline Trauma & 8 & $5(62.5 \%)$ & & $0.699^{b}$ \\
\hline Shock/sepsis & 4 & $4(100 \%)$ & & $0.324^{b}$ \\
\hline \multicolumn{5}{|c|}{$\begin{array}{l}\text { a Fisher-Freeman-Halton exact test. } \\
\text { b Fisher's exact test. } \\
\text { 'Pearson chi-square test. } \\
\text { SCI/SCIE: Scientific Citation Index/Scientific Citation Index Expended. }\end{array}$} \\
\hline
\end{tabular}

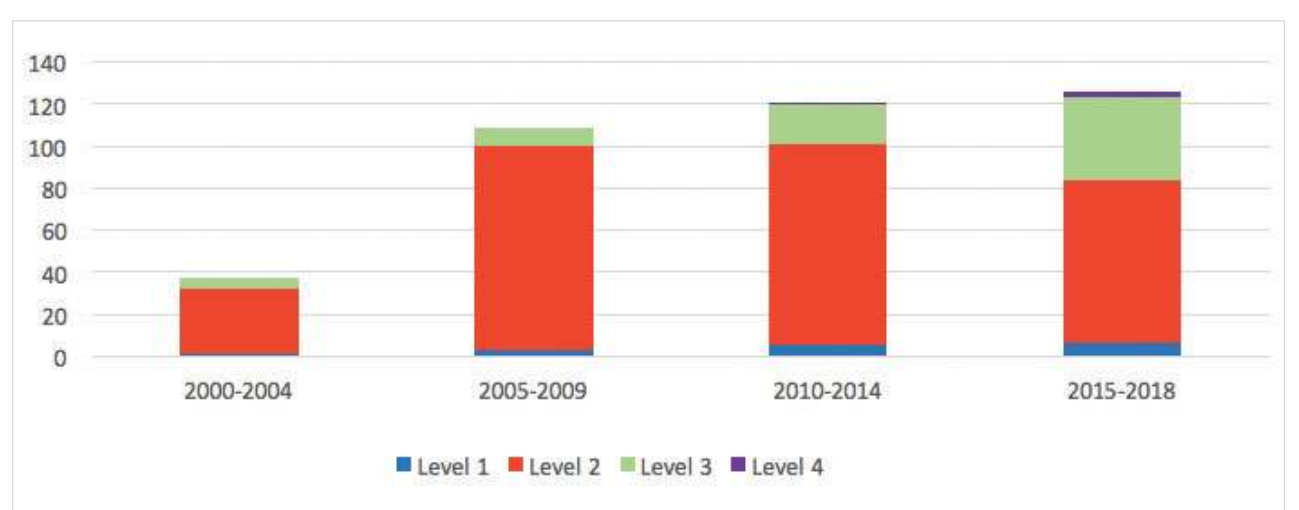

Figure 3. Evaluation of the theses according to Levels of Evidence and Grades of Recommendation System evaluation.

\section{DISCUSSION}

According to regulations of residency in medical doctorate and dentistry in Turkey, medical doctors (residents) are obligated to prepare and advocate a medical thesis in their field at the end of their training program (8). Idea setup, questioning, creating the study protocol, collecting the datum, assembling the results, arising the conclusions and concluding a clinical implication are steps of generating a scientific thesis. Accessibility of the scientific thesis is mostly inadequate, unfeasible or dependent on the accessibility of academic libraries. Publishing these valuable scientific papers in internationally indexed scientific journals is the best way to improve accessibility $(2,9)$.
In this study, we noticed that the publication rates of the theses in the field of general surgery in international and SCI/SCIE indexed journals were $16.9 \%$ and $14.4 \%$, respectively. In the study of Ogrenci et al., publication rate of the theses in $\mathrm{SCl} /$ SCIE indexed journals is 18.2\% (9). Another study from Turkey has revealed that the publication rate of the theses on public health in SCI/SCIE indexed journals is 11.9\% (1). The study of Ozgen et al. revealed that Turkish medical theses written between years 1980 and 2005 revealed that only 6.2\% of the theses were published in MEDLINE indexed journals (6). A recent study of Mayir et al. have also reported that the publication rate of the theses on general surgery in SCI/SCIE indexed journals is 22\% (10). Relevant publications on general surgery in the literature 
have notified this ratio between $17 \%$ and 52\% (11-13). Factors considered as obstacles in the release of the theses include the lack of sufficient information in the residency programs on the writing of scientific papers, incapability of writing in foreign languages and the lack of motivating regulations for preparing a scientific publication (14). However, we are of the opinion that the most instrumental reasons of low publication rates may be the inability to allocate sufficient time for developing academic skills due to the excessive workload and the residents' view of the theses as only a ritual or necessity for the completion of the residency program. Lack of motivation in surgery residents could be another cause for low publication rates of the theses since they need to publish their theses in SCl/SCl-E-indexed journals only for the purpose of academic career and clinical promotions in a limited time period of their profession $(1,2)$. In a study presented by Hollmann et al., reasons for not publishing theses have included work load, bias for negative results, insufficient tutor support, insufficient motivation/ personal interest, and family burdens (2). It is also possible that some other theses might have reached publication status after timepoint of retrieval of the dataset in this study. Namdari et al. have shown an inverse correlation between decreasing work-hours and increasing scientific publication rates in medical residents (15). Time spent doing research is the primary determinant of scientific productivity (16). A mentoring program designed for improving scientific skills also has a positive influence on publication rates of the residents (17).

It was seen in this study that an increase was observed in the number of published theses over time, which is compatible with the literature (6). We believe that this increase might be associated with the rise in the number of institutions having residency programs in Turkey.

Although the number of clinical studies was higher, we found that experimental studies were more published in SCI/SCIE indexed journals $(p=0.007)$. This result correlates with the results of Ogrenci et al. (9).

According to research methodologies, half of the theses were experimental studies. However, as indicated in Figure 2, there is an increasing tendency to clinical studies and quality of the theses demonstrates an upgrading pattern, which is shown in Figure 3. The presented research also reveals that experimental studies have significantly higher publishing rates. The reason of this difference is that clinical studies need more effort, take longer time to be finalized, longer length of follow-up facilitates the loss of patients, and experimental studies have more potential to provide original information which provides a higher potential for scientific publication (10). Although prospective randomized studies are the most valuable studies, these factors create a tendency on residents to compose experimental theses. But in recent years, there has been an increase in the number of clinical studies, which is thought to be due to developments in hospital computing systems and computer technologies that has increased and eased the possibility of data access.

In the study presented here, theses subjecting the diseases of peritoneum/omentum and skin/wound healing had higher publication rates ( $p=0.003$ and $p=0.022$; respectively), and the most dominantly published theses in SCI/SCIE indexed journals were conducted on the intestines/colon/rectum/anus ( $n=75)$. All theses on peritoneum/omentum and skin/wound healing were experimental studies with a higher potential of publishing in SCI/SCIE journals.

Limitations of this study include the website of National Thesis data center of Higher Educational Council of the Republic of Turkey that only collects theses written at university hospital clinics, database center has excluded theses conducted at training hospitals affiliated by Ministry of Health up to 2015, and National Thesis data center records were not complete and the exclusion of the theses which did not allow open access reading. In addition, the indexation status of the journals is variable (i.e., SCl and SCIE are dynamic in and out situations).

\section{CONCLUSION}

Surprisingly, an excessive proportion of medical doctoral theses are never published, as recorded by the two international online databases for scientific literature. The main reason for this problem is that the majority of the theses consist of low-level studies and experimental studies. The quality of medical theses needs to be improved, and adequate measures should be taken to advance the scientific merit. We believe that this problem can be solved by encouraging residents to publish in high-quality journals and residents who do not publish their theses, be deemed incomplete in the residency program.

\section{Ethics Committee Approval: Not relevant.}

Peer-review: Externally peer-reviewed.

Author Contributions: Concept - M.F.F.; Design - M.F.F., A.I.F.; Supervision - A.K.; Resource - M.F.F.; Materials - M.F.F., T.K.; Data Collection and/or Processing - M.F.F.; Analysis and Interpretation - M.F.F.; Literature Search - M.F.F.; Writing Manuscript - M.F.F.; Critical Reviews - A.K.

Conflict of Interest: The authors have no conflicts of interest to declare.

Financial Disclosure: The authors declared that this study has received no financial support.

\section{REFERENCES}

1. Sipahi H, Durusoy R, Ergin I, Hassoy H, Davas A, Karababa A. Publication rates of public health theses in international and national peer-review journals in Turkey. Iran J Public Health 2012;41:31-5. [CrossRef]

2. Hollmann M, Borrell C, Garin O, Fernandez E, Alonso J. Factors influencing publication of scientific articles derived from masters theses in public health. Int J Public Health 2015;60:495-504. [CrossRef] 
3. Arriola-Quiroz I, Curioso WH, Cruz-Encarnacion M, Gayoso O. Charac teristics and publication patterns of theses from a Peruvian Medical School. Health Info Libr J 2010;27:148-54. [CrossRef]

4. Bordons M, Zulueta MA. Evaluation of the scientific activity through bibliometric indices. Rev Espanola Cardiol 1999;52:790-800. [CrossRef]

5. Figueredo E, Sanchez Perales G, Villalonga A, Castillo J. Spanish doctoral dissertations on anesthesiology and the scientific publications of their authors. Rev Esp Anestesiol Reanim 2002;49:124-30. [CrossRef]

6. Ozgen U, Egri M, Aktas M, Sandıkkaya A, Ozturk OF, Can S, et al. Publication pattern of Turkish medical theses: analysis of 22,625 medical theses completed in years 1980-2005. Turkiye Klinikleri J Med Sci 2011;31:1122-31. [CrossRef]

7. American Academy of Orthopaedic Surgeons. Levels of Evidence and Grades of Recommendations. http://www2.aaos.org/bulletin/apr05/ fline9.asp Accessed 21 March 2015. [CrossRef]

8. The Official Gazette of Republic of Turkey: 26.04.2014, 28983. [CrossRef]

9. Ogrenci A, Eksi MS, Ozcan Eksi EE, Koban O. From idea to publication: publication rates of theses in neurosurgery from Turkey. Neurol Neuroshir Pol 2015;50:45-7. [CrossRef]

10. Mayir B, Bilecik T, Cakır T, Dogan U, Gundur UR, Aslaner A, et al. Analysis of the publishing rate and the number of citations of general surgery dissertations. Turk J Surg 2017;33:33-5. [CrossRef]
11. Salmi LR, Gana S, Mouillet E. Publication pattern of medical the- ses, France, 1993-98. Med Educ 2001;35:18-21. [CrossRef]

12. Frkovic V, Skender T, Dojcinovic B, Bilic-Zulle L. Publishing scientific papers based on Master's and Ph.D. theses from a small scientific community: case study of Croatian medical schools. Croat Med J 2003:44:107-11. [CrossRef]

13. Caan W, Cole M. How much doctoral research on clinical topics is published? Evid Based Med 2012;17:71-4. [CrossRef]

14. Dhaliwal U, Singh N, Bhatia A. Masters theses from a university medical college: publication in indexed scientific journals. Indian J Ophthalmol 2010;58:101-4. [CrossRef]

15. Namdari S, Baldwin KD, Weinraub B, Mehta S. Changes in the number of resident publications after inception of the 80-hour work week. Clin Orthop Relat Res 2010;468:2278-83. [CrossRef]

16. Gutovich JM, Den RB, Werner-Wasik M, Dicker AP, Lawrence YR. Predictors of radiation oncology resident research productivity. J Am Coll Radiol 2013;10:185-9. [CrossRef]

17. Chassagnon G, Dangouloff-Ros V, Vilgrain V, Ronot M. Academic productivity of French radiology residents: where do we stand? Diagn Interv Imaging 2016;97:211-8. [CrossRef]

\section{ORIJINAL ÇALIŞMA-ÖZET}

Turk J Surg 2020; 36 (1): 9-14

\section{Türkiye'de 1998-2018 yılları arasında yapılan genel cerrahi tezlerinin analizi: 1996 tezin kanıt düzeyleri ve yayın oranlarının değerlendirilmesi}

Murat Ferhat Ferhatoğlu ${ }^{1}$, Taner Kıvılcım¹ , Abdulcabbar Kartal ${ }^{1}$, Ali Illker Filiz ${ }^{1}$, Abut Kebudi ${ }^{1}$

${ }^{1}$ Okan Üniversitesi Tıp Fakültesi, Genel Cerrahi Anabilim Dalı, İstanbul, Türkiye

\section{ÖZET}

Giriş ve Amaç: Türkiye'de tıp uzmanlığı ile ilgili yönetmeliklere göre genel cerrahi uzmanı olmak için eğitim programının sonunda bir tez hazırlamak ve savunmak zorunludur. Bir tezin kurgulanması eğitimi devam eden uzman adayının; sorular sormayı, en doğru çalışma tasarımını birleştirmeyi, çalışma sürecini yönetmeyi, sonuçları toplamayı ve bilimsel çıkarımlar oluşturmayı öğrenmesine yardımcı olur. Bu tanımlayıcı çalışmada, genel cerrahi alanında yazıımış tezlerin yayın oranlarını araştırmak ve yayınlanmış tezlerin özelliklerini değerlendirmek amaçlanmıştır.

Gereç ve Yöntem: Yüksek Öğretim Kurumu Tez Merkezinin internet sitesinde genel cerrahi uzmanlarının tezleri ile ilgili araştırma gerçekleştirildi ve 1998-2018 yılları arasında tamamlanan tezler analiz edildi. Tezlerin yayınlanma durumuna, PubMed, Google Akademik ve Ulusal Akademik Ağ ve Bilgi Merkezi (ULAKBIM) veri tabanlarının arama motorları kullanılarak yazar adı, tezlerin başlığı ve tezlerin anahtar kelimeleri aranarak bakıldı. Veriler, mutlak sayılar ve yüzdeler olarak sunuldu.

Bulgular: Çalışmada, 1998-2018 yılları arasında tamamlanan 1996 tez değerlendirilmiştir. Bu tezlerin 393 (\%20,5)'ü bilimsel bir dergide, bunların da $288(\% 14,4)^{\prime}$ i SCI/SCIE endeksli bir dergide yayınlanmıştır. Araştırma yöntemlerine göre, deneysel çalışmaların \%79,2'si SCI/SCIE endeksli dergilerde yayınlanmıştır.

Sonuç: Genel cerrahi alanındaki tezlerin yayın oranları, diğer tıp uzmanlıklarında olduğu gibi düşüktür. Bu tanımlayıcı çalışma, genel cerrahi tezlerinin bilimsel dergilerdeki düşük yayın oranları hakkında bir fikir verebilir. Bu yetersiz bilimsel performanstan sorumlu olan altta yatan faktörleri anlamak için daha fazla çalışmaya ihtiyaç vardır.

Anahtar Kelimeler: Tez, yayın, asistan, genel cerrahi, cerrahi eğitim

Doi: 10.5578/turkjsurg.4405 